\title{
Keynote
}

Prologi - puheviestinnän vuosikirja 2020

\section{Sosiaalisen identiteetin näkökulma vuorovaikutukseen}

\author{
Janne Matikainen \\ Dosentti, yliopistonlehtori \\ Helsingin yliopisto, viestinnän oppiaine \\ janne.matikainen@helsinki.fi
}

Keynote-puheenvuoro Vuorovaikutuksen tutkimuksen päivillä 18.-19.9.2020

Erilaisia sosiaalisia ilmiöitä on viime vuosikymmeninä tutkittu runsaasti sosiaalisen identiteetin teorian näkökulmasta. Teoriasta on tullut sosiaalipsykologisen tutkimuksen valtavirtaa, sillä on selitetty niin ryhmien välisiä suhteita, vihapuhetta netissä kuin joukkoilmiöitä. Yllättävää kyllä, sosiaalisen identiteetin teoriaa on sovellettu melko vähän välittömän vuorovaikutuksen tutkimukseen. Tässä puheenvuorossa esitän näkökulmia sosiaalisen identiteetin ja vuorovaikutuksen väliseen yhteyteen. Aluksi hieman avaan sosiaalisen identiteetin teoriaa, minkä jälkeen tarkastelen sen suhdetta vuorovaikutukseen. Erityisen huomion kiinnitän siihen, kuinka sosiaalisen identiteetin teoriaa on sovellettu internetin tutkimukseen, esimerkiksi vihapuheen tarkasteluun.
Sosiaalisen identiteetin teorian esitteli ensimmäisenä Henri Tajfel, joskin samansuuntaisia näkemyksiä oli jo aiemmin esitetty (Burr, 2004). Teorian keskeinen ajatus on, että identiteettimme ei ole vain persoonallinen vaan myös sosiaalinen perustuen ryhmäjäsenyyksiimme. Tällöin erottelu sisä- ja ulkoryhmiin on keskeinen sosiaalisen maailman jäsentämisen periaate. Ihmisillä on luontainen taipumus luokitella ryhmiä niihin, joihin kuulumme ja niihin, joihin emme kuulu. Meillä on myös taipumus nähdä oma ryhmämme myönteisessä valossa, mikä on varsin luonteva ajatus.

Täsmällisemmin ilmaistuna sosiaalisessa identiteetissä on kolme prosessia (Burr, 2004). Ensimmäinen on luokittaminen, havaintomme maailmasta perustuvat kategorioihin, esimer- 
kiksi nainen-mies-kategoriassa usein asetumme jompaankumpaan kategoriaan, mutta jotkin kategoriat ovat haastavampia. Samaistumalla kategorioihin tuotamme identiteettimme. Ja edelleen samaistuessamme johonkin ryhmään, arvotamme omaa ryhmää ja identiteettiä vertaamalla sitä toisiin ryhmiin. Huomattavaa on, että ryhmien vertailua tehdään usein hyvinkin automaattisesti.

Sosiaalisen identiteetin olemuksesta ja runsaasta tutkimuksesta on syytä nostaa esille muutamia näkökulmia. Ryhmäjäsenyydet voivat olla annettuja tai hankittuja. Tämä on arkisestikin selkeä ajatus. Osa jäsenyyksistä tulee meille jo syntyessämme, ei ainoastaan biologiset, vaan myös sosiaaliset, kuten kansallisuus. Se on melkoisen pysyvä jäsenyys, joskin muutettavissa. Selkeitä eroja on siinä, miten annetut tai hankitut ryhmäjäsenyydet vaikuttavat sosiaaliseen vertailuun. Aika usein vertailu perustuu melko lailla annettuihin tai ainakin melko pysyviin ryhmäjäsenyyksiin, kuten sukupuoleen, rotuun tai kansallisuuteen.

Ryhmien väliset status- ja valtaerot vaikuttavat vertailuun. Samastumme mielellään korkean statuksen omaaviin ryhmiin, joskin statuserot eivät ole yksiselitteisiä. Eri ihmisille korkean statuksen ryhmät vaihtelevat, vaikkapa sen mukaan, mitä urheilujoukkuetta kannatetaan. Vertailua tehdään myös mieluummin omaa ryhmää alemman kuin ylemmän statuksen ryhmiin, ellemme pyri kohti ylempänä olevaa ryhmää. Tästä löytyy myös selkeä linkki itsetuntoon. Samastuessamme alemman statuksen ryhmiin voi se myös heikentää itsetuntoamme sekä päinvastoin. On tosin syytä huomata, että sosiaaliseen identiteettiin sitoutumisessa on eroja. Identiteetin määrittely voi perustua painokkaammin joko ryhmäjäsenyyksiin tai henkilökohtaisiin ominaisuuksiin. Tämä voi vaihdella paitsi henkilöittäin myös tilanteittain.
Tärkeää onkin muistaa sosiaalipsykologialle ominainen tilanteisuus eli sosiaaliset ilmiöt eivät ole pysyviä, vaan ne muotoutuvat ja rakentuvat erilaisten tilanteiden mukaan.

Sosiaalisen identiteetin ja vuorovaikutuksen tarkastelussa on hyvä palauttaa mieliin Willem Doisen (1982) muotoilemat sosiaalipsykologian selitystasot:

\section{- $\quad$ yksilönsisäinen taso \\ - $\quad$ yksilöiden välinen taso \\ - asemien tai ryhmien välisten suhteiden taso \\ - $\quad$ ideologinen ja joukkojen taso}

Sosiaalisen identiteetin tutkiminen on asettunut erityisesti ryhmien välisten suhteiden tasolle, mutta myös muille tasoille. Tosin melko vähän yksilöiden väliselle tasolle eli vuorovaikutuksen tasolle, joka on nyt mielenkiinnon kohteena. Doisen jaottelu on hyödyllinen sen hahmottamisessa, että voimme tarkastella monia ilmiöitä, kuten sosiaalista identiteettiä, eri tasoilla, jolloin näkökulmat ja painotukset ovat hieman erilaisia. Vuorovaikutuksen tutkimuksen kannalta on erityisen tärkeää huomata, että sosiaalisen identiteetin tutkimus ei ole kovin vahvasti ollut yksilöiden välisellä eli vuorovaikutuksen tasolla.

Tiettävästi ensimmäinen tutkimus sosiaalisesta identiteetistä vuorovaikutuksessa on niinkin myöhään kuin 2005 (Nezlek \& Smith, 2005) tai ainakin tutkimuksen tekijät näin väittävät. Tutkimuksen tuloksena todettiin, että sisäryhmän jäseniin suhtauduttiin vuorovaikutuksessa myönteisemmin kuin ulkoryhmän jäseniin. Tämä on tietysti melko odotettu tulos, tosin muitakin vaihtoehtoja voisi olla. Voisihan nimittäin olla niin, että ryhmän sisäisessä kilpailutilanteessa toisiin jäseniin suhtaudutaan negatiivisesti ja tukea haetaan ulkoryhmästä, 
varsinkin statusarvoltaan korkeammalta tasolta. Nezlekin ja Smithin tutkimuksessa todettiinkin, että dominanssi niin sisä- kuin ulkoryhmissä lisäsi myönteistä vuorovaikutusta.

Tämän tutkimuksen pohjalta nousee vääjäämättä havainto, että välittömän vuorovaikutuksen suhde sosiaaliseen identiteettiin on vaikea tutkia. Sosiaalinen identiteetti on tavallaan taustatekijä, joka on läsnä vuorovaikutuksessa, mutta joka ei suoraan näy. Pelkkää vuorovaikutusta tutkimalla voi olla vaikea metodisesti päästä kiinni sosiaaliseen identiteettiin.

Koetan valaista asiaa parilla esimerkillä, joista ensimmäisessä sosiaalinen identiteetti ei suoraan näy vuorovaikutuksessa ja toisessa se on taas vuorovaikutuksen keskiössä. Ensimmäisessä esimerkissä (kuvio 1) on keskusteluanalyysin keinoin analysoitu yhteisopettajien keskustelua
(Korpi, 2010). Kyseessä on eri statuksilla toimivat opettajat: luokanopettaja ja lastentarhanopettaja. Näytteessä käy hyvin ilmi, että hierarkiassa ylempänä oleva luokanopettaja avaa vuorovaikutuksen ja määrittelee tilanteen kulun sekä antaa alempana hierarkiassa olevalle lastentarhanopettajalle luvan - ilmeisesti poikkeuksellisesti - kertoa ohjeet oppilaille. Näytteestä käy hyvin ilmi, että osapuolet toimivat vahvasti oman ammatillisen eli sosiaalisen identiteetin pohjalta ja myös tiedostavat omat ja toistensa identiteetit.

Toinen näyte on verkkokeskustelusta (kuvio 2). Tässä näytteessä sosiaaliset identiteetin ovat vahvasti läsnä. Itse asiassa koko viesti perustuu sosiaalisille luokituksille, joilla kirjoittaja määrittelee omaa ja toisten sosiaalista identiteettiä. Sosiaaliset luokittelut ja identiteetit ovat koko viestin ydintä.

\begin{tabular}{|lc|}
\hline 01 Luokanopettaja: & Jah ((nousee seisomaan)) nyt tuota(.) \\
02 & tulee [meillä] \\
03 Lastentarhanopettaja: & [Joo] \\
04 Luokanopettaja: & semmone jako et Hannelepa sannoo \\
05 & ensin ohjeet \\
06 Lastentarhanopettaja: & Joo (.) tota niinni (.) toi Jonne (.)
\end{tabular}

Kuvio 1. Keskustelunäyte opettajien keskustelusta (Korpi, 2010)

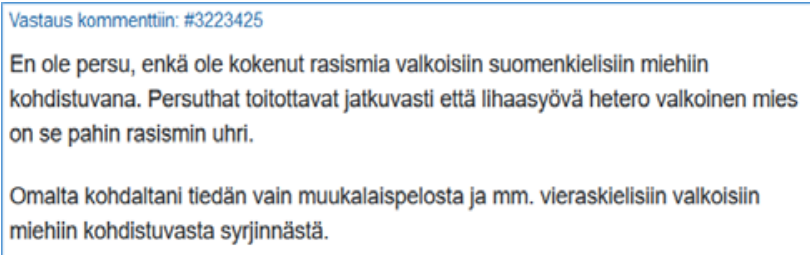

Kuvio 2. Näyte verkkokeskustelusta ${ }^{1}$

\footnotetext{
${ }^{1}$ https://puheenvuoro.uusisuomi.fi/ilkkaporttikivi/peraankuulutan-asiallista-keskustelua-maahanmuutosta/ \#comment-3223425
} 
Sosiaalisen identiteetin teoriaa onkin sovellettu verkkoympäristöön melko paljon. Tunnettu on ns. SIDE-malli eli sosiaalisen samaistumisen/ deindividuaation teoria (social identification/ deindividuation theory) (Spears \& Lea, 1992). SIDE perustuu osaltaan perinteisiin sosiaalista vihjeettömyyttä korostaviin malleihin, mutta lisänä on sosiaalisen identiteetin teoria. Pyrimme siis verkossakin samaistumaan ryhmiin, jotka koemme vetovoimaisiksi ja suosimaan ryhmiä, joihin kuulumme eli sisäryhmiin.

SIDE-mallin lähtökohtana on fyysinen eristyneisyys sekä visuaalinen anonymiteetti ja kohonnut yksityisyys. Näiden lähtökohtien jälkeen nousee esille persoonallisen ja sosiaalisen identiteetin tärkeys sekä epäyksilöllistyminen eli tiivistäen se, onko ryhmä tärkeä vai ei. Näiden tekijöiden pohjalta selitetään ryhmän normeille tai henkilökohtaisille normeille uskollista käyttäytymistä ja siten mahdollista ryhmäpolarisaatiota. Samaistuminen ryhmään on keskeinen välittävä prosessi normatiivisen käyttäytymisen tuottamisessa (Watt ym. 2002, s. 73).

SIDE-malli korostaa sosiaalisen tason eli ryhmäkategorioihin ja ryhmäjäsenyyksiin liittyviä vihjeitä ja sitä, että näitä sosiaalisen tason vihjeitä on verkossa. Vuorovaikutustilanteeseen liittyvät vihjeet saattavat kuitenkin suodattua pois, kuten monet perinteiset verkkovuorovaikutusta selittävät vihjemallit olettavat (Watt ym., 2002, s. 69). Sosiaalisuuden ja sosiaalisen identiteetin painotuksesta seuraa ero perinteisiin verkkovuorovaikutuksen anti-normatiivisuutta korostaviin malleihin. Vuorovaikutus verkossa voi siis olla myös normatiivista eli ryhmän normeihin sitoudutaan yhteisen sosiaalisen identiteetin vuoksi.

On jopa väitetty, että joskus sosiaalinen toiminta voi verkossa olla normatiivisempaa ja sosiaa- lisesti säännellympää kuin kasvokkain (Spears \& Postmes, 2015). Tämän mallin pohjalta on siis selitettävissä normatiivinen käyttäytyminen verkossa ja siten ryhmien ja yhteisöjen mahdollisuus verkkoympäristöissä. Voimakas samastuminen johonkin ryhmään voi puolestaan lisätä ryhmien välisiä eroja ja jopa vihamielisyyttä (Hankonen ym., 2007). Tällöin epäsosiaalisuus ei ilmene niinkään yksilöiden vaan ryhmien välillä.

Sosiaalisen identiteetin kannalta tärkeä havainto verkossa on, että identiteetti voi perustua vain joihinkin identiteetin osiin. Voidaan ajatella, että sosiaalisessa identiteetissä on osia, joista ihminen voi verkossa valita mitä tuo esille ja mitä ei. Kasvokkaisessa maailmassa tämä voi olla mahdotonta tai hyvin vaikeaa. Tähän liittyy depersonalisaation ilmiö, jossa persoonallinen minuus korvautuu ryhmäjäsenyyteen perustuvalla minuudella. Depersonalisaation johdosta ryhmien kyseenalaisiin ja haitallisiin normeihin sitoudutaan, koska henkilön identiteetti rakentuu ryhmän varaan (Keipi ym., 2017.) Depersonalisaatio ei kuitenkin tarkoita identiteetin kadottamista, vaan sosiaalisen identiteetin ja varsinkin joidenkin sosiaalisen identiteetin osien ylikorostumista.

Myös viharyhmien ja vihapuheen selittämisessä ja ymmärtämisessä on paljon nojauduttu sosiaalisen identiteetin teoriaan (Kaakinen, 2018). Verkossa saattavat siis vain jotkin ryhmäjäsenyydet korostua ja toiset jäädä taka-alalle, toisin kuin kasvokkaisessa maailmassa. Tämän vuoksi esimerkiksi poliittiset tai etnisiin ryhmiin liittyvät näkemykset saattavat verkossa olla suurempi osa identiteettiä kuin muutoin. Tällöin näkemyksiin saatetaan myös sitoutua yksipuolisen vahvasti, mikä voi lisätä vihapuheen mahdollisuutta. 
Samastumista sosiaaliseen identiteettiin vahvistaa myös henkilön persoonallinen tai sosiaalinen epävarmuus (Kaakinen, 2018, s. 28). Tällöin ryhmään sitoutuminen hälventää epävarmuutta. Vahva samastuminen sisäryhmään tarkoittaa myös ulkoryhmän dehumanisointia eli ulkoryhmään liitetään epäinhimillisiä piirteitä, mikä helpottaa ulkoryhmää kohtaan esitettyä aggressiivista viestintää ja vihapuhetta.

Sosiaalisen identiteetin teoria auttaa ymmärtämään, miksi ihminen tuntee vetoa viharyhmiä kohtaan. Verkossa sosiaalista identiteettiä voidaan rakentaa vahvasti tiettyjen ominaisuuksien tai piirteiden pohjalle. Verkossa yhteen asiaan keskittyvät ryhmät ja yhteisöt ovat yleisempiä kuin kasvokkain, jolloin myös identiteetti rakentuu tämän yhden asian ympärille. Tätä taustaa vasten on ymmärrettävissä Suomessakin paljon vihapuhetta aiheuttanut keskustelu ulkomaalaisista. Verkossa helpommin sitoudutaan yksipuolisesti asian vastustajaksi tai puolustajaksi.

Kun tarkastellaan identiteettiä verkossa, on kiinnostavaa pohtia sitä, miten identiteettiä tuotetaan tiedostaen ja jopa tavoitteellisesti. Tätä ilmiötä kuvaa hyvin sosiaalipsykologi Suvi Uskin (2015) muotoilema profiilityön käsite. Profiilityö tarkoittaa strategista minän esittämistä, jonka tavoitteena on positiivisen ja aidon kuvan tuottaminen. Profiilityössä on sekä tiedostettu että tiedostamaton osa. Kyse on työstä, jota henkilön on tiedostamatta tai tiedostaen tehtävä, jotta hän tuottaa myönteisen identiteettiesityksen sosiaaliseen mediaan. Profiilityö soveltuu erityisesti sosiaalisen median palveluihin, joissa käyttäjien on luotava oma profiili.

Profiilityön taustalla ovat havainnot muuttuneesta identiteettiesityksen dynamiikasta (Uski, 2015). Ensimmäinen muutos koskee päällekkäisiä yleisöjä. Arkisessa elämässä roolit jakau- tuvat sen mukaan, missä kulloinkin olemme. Kotona meillä on eri rooli kuin työpaikalla tai harrastuksissa. Sosiaalisessa mediassa eri roolit sekoittuvat ja voivat aiheuttaa rooliristiriidan. Tällöin meidän on tehtävä profiilityötä, jotta onnistuneesti yhdistämme eri roolit ja esitämme identiteettiämme onnistuneesti eri yleisöille.

Toinen identiteettiesityksen muuttunut dynamiikka liittyy ajan muuttuneeseen luonteeseen. Verkko on aina auki, siellä ovat niin uudet kuin vanhat asiat. Identiteetin kannalta tämä tarkoittaa sitä, että teemme identiteettityötä aina, myös silloin kun emme ole verkossa, koska muut käyttäjät voivat nähdä profiilityömme jälkiä. Goffmannin termein olemme näyttämöllä koko ajan. Ajallisuuteen liittyy myös se, että verkkoon ja some-palveluihin kertyy elämänhistoriaamme pitkältä ajalta. Julkaisut eivät ole vain tätä päivää, vaan voivat olla vuosikymmenenkin ikäisiä. Joudumme siis profiilityössä ottamaan huomioon menneisyyden ja jatkuvan näyttämöllä olemisen.

Kolmas muuttunut dynamiikka liittyy välittyneisyyteen. Tällöin emme ole suoraan kontaktissa toisiin ihmisiin ja yleisöihin, vaan välittyneesti. Tämä tarkoittaa myös sitä, että mahdollisuutemme vaikuttaa ja kontrolloida identiteettiämme ovat heikommat kuin kasvokkaisessa vuorovaikutuksessa. Tämä lisää identiteettiesityksen eli profilityön harkinnanvaraisuutta.

Näiden muuttuneiden dynamiikkojen pohjalta siis teemme profiilityötä. Käytännössä tämä tarkoittaa julkaisemiseen liittyvien kysymysten pohdintaa: Mitä julkaisen, sisältö, kuvat, tekstit? Milloin ja kuinka usein julkaisen? Rajoitanko julkaisujeni näkyvyyttä? Miten kommentoin muiden julkaisuja? Ja lopulta päädytään profii- 
lityön keskeiseen kysymykseen, millaisen kuvan luon itsestäni.

Identiteetti ja varsinkin sen eheys on olemassaolomme ja mielenterveytemme kannalta tärkeää. Identiteetin ylläpitämiseksi on monia suojaamis- ja puolustusmekanismeja. Sosiaalisen median palvelut tuovat identiteetille uusia uhkia. Uski (2015) esittää neljä sosiaalisen median mukanaan tuomaa uhkaa. Ensimmäinen uhka liittyy siihen, että sosiaalisen median palvelut eivät tue identiteetin kehitystä. Kun sosiaalisen median käyttö jatkuu pitkään, on palveluissa päivityksiä, kuten kuvia, varhaisemmista elämän vaiheista. Nämä aiemmat päivitykset voivat kuormittaa identiteettiä, jos ne esimerkiksi ovat teinivuosilta. Monet aiempiin vuosiin ja nuoruuteen liittyvät asiat unohtuvat, mutta sosiaalisen median palvelut voivat niistä muistuttaa vuosienkin jälkeen ja siten kuormittaa - tosin joskus ne voivat ilahduttaakin.

Toinen uhka liittyy päällekkäisiin yleisöihin ja niiden mukanaan tuomaan identiteetti- tai rooliristiriitaan. Tunnetusti erilaisten roolien esittäminen on meille vaativaa. Kuitenkin roolit liittyvät kulloiseen kontekstiin: työpaikalla voimme olla työroolissa, mikä voi poiketa paljonkin koti-roolista tai sukulais-roolista. Kun nämä yhdistetään, voi identiteetin yhdenmukainen koossapitäminen käydä vaativaksi, kun pitäisi tehdä kullekin osayleisölle sopivia minä-esityksiä. Kolmas uhka on identiteetti-esityksen pitkittyneisyys, mikä liittyy identiteetin alituiseen käynnissä olemiseen. Tällöin yhdenmukaisen eri tilanteissa pätevän identiteetti-esityksen tuottaminen voi olla hyvin haastavaa ja kuormittavaa.

Neljäs identiteetin uhka on aitous. Sosiaalisen median palvelut tarjoavat lukuisia mahdollisuuksia tuottaa muunneltua tai kiillotettua identiteettiä. Mikäli identiteetti-esityksemme on kovin suunniteltu, voi kuilu todellisen ja somessa tuotetun identiteetin välillä kasvaa suureksi, mikä kuormittaa ja uhkaa identiteettiämme.

Sosiaalisen identiteetin teoria on auttanut ymmärtämään monia verkon ja sosiaalisen median vuorovaikutukseen liittyviä ilmiöitä. Verkon luonteen vuoksi sosiaalisen identiteetin näkökulmaa on täydennettävä profiilityön kaltaisilla käsitteillä, jotka tuovat esille identiteettityön suunnitelmallisuuden ja strategisuuden verkossa.

Koska alussa hieman viittasin joukkojen toimintaan, niin pari sanaa sosiaalisesta identiteetistä joukkojen toiminnan selittäjänä. Alkujaan joukkojen toiminta nähtiin - ja nähdään edelleen usein - irrationaalisina. Tätä näkökulmaa edusti varsinkin joukkojen toiminnasta 1800-luvun lopussa kirjoittanut Gustave Le Bon, jonka mukaan ihmisen psyykkinen taso laskee joukoissa, anonyymina toimijana ihminen ei ota vastuuta ja tunnetilat leviävät joukoissa epidemian tavoin (Helkama ym., 2020). Le Bonin näkemys on kuitenkin yksipuolinen, eikä ota huomioon erilaisia joukkoja.

Sittemmin joukkojen toimintaa on selitetty sosiaalisen identiteetin teorialla, esimerkiksi mellakka ei ole sattumanvarainen, vaan nojaa tiettyyn logiikkaan ja ryhmänormeihin. Mellakka voi kohdistua vain tiettyihin kohteisiin, eikä suinkaan sattumanvaraisesti. Tätä kirjoitettaessa Valko-Venäjällä on ollut koko syksyn suuret mielenosoitukset. Suuret joukot ovat olleet liikkeellä, mutta toiminta on ollut harkittua, rauhanomaista ja sillä on selkeä päämäärä. Joukkojen toiminnassa onkin huomioitava erilaiset joukkotapahtumat ja -liikkeet, joidenkin toiminta on organisoituneempaa kuin toisten. Ja vaikka sosiaalinen identiteetti on onnistunut hyvin selittämään joukkojen toimintaa, se ei 
sitä yksistään selitä, vaan joukkojen toiminnassa on monia yhteiskunnallisia ja historialliseen hetkeen liittyviä tekijöitä.

Lopuksi muutama keskeinen päätelmä: sosiaalinen identiteetti tuo esille erilaisten selitystasojen merkityksen vuorovaikutuksen tutkimuksessa. Keskittymällä ainoastaan näkyvään vuorovaikutukseen voi jotain keskeistä jäädä huomaamatta. Sosiaalinen identiteetti nostaa esille ryhmäjäsenyydet ja ryhmien väliset suhteet. Voidaankin sanoa, että sosiaalisen identiteetin näkökulma kiinnittää huomion siihen, mikä ei näy vuorovaikutuksessa. Tai ainakin se näkyy heikosti. Tällaista on tietysti aina vaikea tutkia. Sosiaalisen identiteetin tutkimus on toki ollut laajaa ja myös menetelmällisesti kehittynyttä, mutta haaste syntyy siitä, miten tutkia sosiaalisen identiteetin yhteyttä välittömään vuorovaikutukseen.

\section{Kirjallisuus}

Burr, V. (2004). Sosiaalipsykologisia ihmiskäsityksiä. Tampere: Vastapaino.

Doise, W. (1982). Levels of explanation in social psychology. Cambridge: Cambridge University Press.

Hankonen, N., Ristolainen, H., \& Lehtinen, V. (2007). Sosiaalipsykologisia lähestymistapoja verkkovuorovaikutukseen. Psykologia, 42(4), 276-288.

Helkama, K., Myllyniemi, R., Liebkind, K., Ruusuvuori, J., Lönnqvist, J-E., Hankonen, N., Renvik, T. A., Jasinskaja-Lahti, I., \& Lipponen, J. (2020). Johdatus sosiaalipsykologiaan. Helsinki: Edita.

Kaakinen, M. (2018). Disconnected online: A social psychological examination of online hate. Tampere University Press. https://trepo.tuni.fi/ handle/10024/103681

Keipi, T., Näsi, M., Oksanen, A., \& Räsänen, P. (2017). Online Hate and Harmful Content. Cross-National Perspectives. London: Routledge.

Korpi, M. (2010). Samanaikaisopettajien vuorovaikutus oppitunneilla. Keskustelunanalyyttinen tutkimus. Jyväskylän yliopiston kasvatustieteiden laitos.

Nezlek, J. B., \& Smith, V. (2005). Social Identity in Daily Interaction. Self and Identity, 4(3), 243-261.
Spears, R., \& Postmes, T. (2015). Group Identity, Social Influence, and Collective Action online. Extensions and Applications of the SIDE Model. Teoksessa, S. S. Sundar (toim.), The Handbook of the Psychology of Communication Technology (s. 23-46). Chichester: John Wiley.

Spears, R., \& Lea, M. (1992). Social influence and the influence of the 'social' in computer-mediated communication. Teoksessa M. Lea (toim.), Contexts of Computer-Mediated Communication (s. 30-65). New York: Harvester Wheatsheaf.

Uski, S. (2015). Profile Work for Authenticity. Self-presentation in Social Network Services. Doctoral dissertation. Publication of the Department of Social Research, 2015:18.

Watt, S. E., Lea, M., \& Spears, R. (2002). How Social is Internet Communication? A Reappraisal of Bandwith and Anonymity Effects. Teoksessa S. Woolgar (toim.), Virtual Society? Technology, Cyberbole, Reality (s. 61-77). Oxford: Oxford University Press. 